\title{
Authorized Failure: How is Company Status?
}

Fiany Alifia Lasnita ${ }^{1}$, Muhamad Adji Rahardian Utama ${ }^{2}$ ${ }^{1}$ Faculty of Law, Universitas Sebelas Maret, Indonesia ${ }^{2}$ Faculty of Law, Universitas Negeri Semarang, Indonesia Corresponding Author: M.A.R Utama, email: adji.info@gmail.com

\begin{abstract}
:
The sense of the limited liability company is a legal entity to be able to run a business that has a capital consisting of a share, which its owners have lots of stock. Because it is composed of capital over shares that can be traded, and changes to the ownership of the company can be done without the need for a dissolution of a company. Limited liability company is a business entity and the magnitude of the capital company which are poured in a basic budget. The wealth of the company separated from the personal wealth of the owners of the company so that it can have its own treasures. Each person can have more than one stock which can be a proof of ownership of a company. The owner of the stock itself has a limited liability, i.e. as much as their shares. In the establishment of limited liability company also required permission and also some important documents that should be owned by a limited liability company to be its foundation.
\end{abstract}

Keywords: Limited Libiality Company; Authorized Failure; Permission; Company Status

\section{How to cite:}

Lasnita, F. A., \& Utama, M. A. R. (2020). Authorized Failure: How is Company Status? Indonesian Journal of Advocacy and Legal Services, 2(2), 223-242. https://doi.org/10.15294/ijals.v2i2.37721

\section{A. Introduction}

Finding a job today become very difficult, and limitations of the company in Indonesia restricts human resources are there to get a job. In other conditions, it is not a little human resource there is the thought of making a new effort (to the job itself) that can be applied to work. With the aim of can do and 
pioneering become larger and become a company that will be able to continue to grow. Legal Alliance company that can be formed as a limited liability company (hereinafter as PT), cooperatives, and State-Owned Entreprises. Limited liability company is a business organization which has had its own formal legal entity which had been owned by a minimum of two people with the responsibilities that can only apply on a company with no personal property involving right or with the individual who is in it. On the owner of the PT. capital should not be incharge of a company, as it may designate another person outside the capital owners to become Chairman. Set PT/limited liability the amount of minimum capital is required in a certain amount and various other requirements.

Limited liability company (PT), formerly also known as Naamloze Vennootschaap (NV) which is an Alliance to be able to run a business that has had capital consisting of a share, which its owner has lots of stocks. because the capital is composed of stocks that can be traded, then change the ownership of these companies can be done without the need for the dissolution of a company. Limited liability company is a business entity with the amount of capital the company that poured in a basic budget. The wealth of the company separated from the personal wealth of the owners of the company so that it can have wealth or sending it it. Each person can have more than one stock which can be a proof of ownership of a company. The owner of the shares has limited liability, i.e. as much of the stock they have. If the company's debt exceeded the company's wealth, then the excess of debt is not the responsibility of shareholders. If the existence of corporate profit, then profit is distributed in accordance with the predetermined conditions. The owner of the stock will get a piece of the profits called dividends with the amount depending on the seriousness of the huge profits that accrue to a limited liability company. In addition, the share capital of PT is also derived from the revelation of the results of the bond. The advantage of the owner of the Bonds is that they get a fixed rate regardless of profit or make it loss. ${ }^{1}$

A limited liability company called PT is a legal entity which is the capital of the Alliance, which was formed by the presence of a result of the agreement, and the venture with its capital base has been entirely divided into a stock law based on Law Number 40 of 2007 concerning Limited

\footnotetext{
1 Irawan Soerodjo, "Juridical Implication of Share Cross Holding According to Limited Liability Company Law in Indonesia", Journal of Legal, Ethical and Regulatory Issues Vol. 21 No. 2, 2018, pp. 1-18. See also Novi Eriza, Busyra Azheri and Wetria Fauzi. "Juridical Consequences of Amendments to the Articles of Association of a Limited Liability Company that are not recorded at the Ministry of Law and Human Rights in Indonesia", International Journal of Multicultural and MultireligiousUnderstanding Vol. 6 No. 6, 2019, pp.430-439.
} 
Liability Company (hereinafter as UUPT). ${ }^{2}$ As a legal entity of its own, a limited liability company that was considered as an individual body of individuals who have been able to do their own law, and thus has a wealth of their own, and can also be prosecuted as well as demanding in front of the Court. To be able to be a legal entity, a limited liability company must be able to meet the requirements and the procedures for the attestation of PT itself, as specified in the UUPT, i.e. with the endorsement of the Minister of Justice and human rights The Republic of Indonesia or the Ministry of Justice and human rights. These Ordinances include the submission and examination of the name PT to be established, the manufacture of the articles of Association, article ratification and the Ministry.

As the Central Fellowship, a wealth of PT consists of top-shaped entirely of capital one stock. The founders of the PT obliged to can take part in one of the capitals in the form of stocks and their own stock gets by as a form letter over equity capital. Any shareholder's liability is limited to the capital itself or the stock that has been dimasukkanya into the company (limited liability). All debts of the company can not ditimpakkan to the top of the personal wealth of shareholders, but with only limited shares of shareholders that can be deposited to a company.

Business entity in the form of a group of people or a set of capital there are several that are often found in the literature. The set of people (associatie personen), such as cooperative, Firm, komanditer (Venootschap (CV)) and so on. While it includes the type of the associated community gathered together capital (joint income) one is a limited liability company (PT). Joint income the related capital (Capital Association) is the main feature that is at stake is how much to raise capital without looking at his men. The case is different with people associated in which each person here in the associated effects on the creation of them. ${ }^{3}$

Majority of economists are more likely to choose the form of the company by the form of a limited liability company (PT). The reason is each person the owner of funds always want minimal risk can also be for the sake

2 Republic of Indonesia, Law Number 40 of 2007 concerning Limited Liability Company (UUPT). See also Kyunghoon Kim, "Matchmaking: Establishment of state-owned holding companies in Indonesia." Asia \& the Pacific Policy Studies Vol. 5 No.2, 2018, pp. 313-330.

3 Abdul Muis, Hukum Persekutuan dan Perseroan, Medan, Universitas Sumatera Utara, 2006, pp. 121-122; Andi Kusuma Atmaja, Affifah Kusumadara, and Siti Hamidah, "Kedudukan Izin Prinsip Penanaman Modal Asing Badan Koordinasi Penanaman Modal Sebagai Dasar Pembuatan Akta Pendirian Perseroan Terbatas", Jurnal Selat Vol. 6 No.1, 2018, pp. 95-114; Muhamad Hafizh v, and Nisriina Primadani Fanaro. "Implementasi Doktrin Business Judgement Rule di Indonesia." Ganesha Law Review Vol. 1 No.1, 2019, pp. 77-87. 
of efficiency. ${ }^{4}$ Activities that can be done personally trying with all its consequences and can also be made in the form of cooperation between private or between groups, the other about the shape of the selected business basically depends heavily on many range of both internal and external factors of economic principals that founded the company.

In addition it's also very reasoned why PT lot sought by the perpetrators of the economy itself because in general the PT has the ability to develop themselves, able to withstand potensil capitalization of capital and as a vehicle for profit good to his own advantage as a supporter (the shareholders). 5 This is particularly relevant to the reality that exists in the business environment. Where, economic organization (business entities) owned by conglomerates that controlled several sectors of the economy in the form of is a limited liability company. Starting as a mediocre company (small), then evolves into a giant company, the company owned by the entrepreneur has the ability to develop themselves and give them the advantage for the institution as well as the shareholders.

Because PT gain its status as a legal entity, then all legal deeds perpetrated in the name of company, company's responsibility, not the responsibility of the Board of Directors, Commissioners or shareholders, as the organ of the company. ${ }^{6}$ This is in accordance with the meaning of "limited" from the body of law that he had, while direksinya is not responsible for the deeds of the law done for and on behalf of the company dikelolanya. Then, shareholders of the company shall not be liable in private over the Alliance which is made on behalf of the company and is not responsible for the losses of the company exceeds the value of stocks it owns. ${ }^{7}$ Limited liability company (PT) before Trade Unions set up in the book's third part three title KUH Article 36 to 56 the following changes on the article by Act No. 4 of the year 1971. But the rules on limited liability companies in the

4 Djaidir, Limited Liability Company Law, Presented in One Day Seminar Regarding the Law on Mortgage Rights and the Law on Limited Liability Companies BRI Regional Office of North Sumatra, Medan, 21 June 1997, pp. 1-3; Made Karina Thalia Crisandyna, I. Nyoman Sumardika, and Desak Gde Dwi Arini, "Aspek Perizinan dalam Pendirian Perseroan Terbatas dengan Sistem Online Single Submission", Jurnal Interpretasi Hukum Vol. 1 No.1, 2020, pp. 118-123.

5 Sri Rejeki Hartono, "Beberapa Aspek Permodalan pada Perseroan Terbatas", Paper, National Seminar, Universitas Gadjah Mada, Yogyakarta, 1995, pp. 2-4.

6 Article 1 point 2 UUPT. This law confirms that a Limited Liability Company, hereinafter referred to as a company, is a legal entity that is a capital partnership, established based on an agreement, carrying out business activities with authorized capital wholly divided into shares and fulfilling the requirements stipulated in this law and its implementing regulations.

7 Article 3 (1) UUPT. It is also emphasized that the shareholders of the Company are not personally responsible for the engagement made on behalf of the Company and are not responsible for the Company's losses in excess of the shares owned. 
trade do not comply again with KUH world economic developments and a thriving business both nationally and internationally.

To create a unity of law and the need for a new law that can spur national development especially in the field of the economy and the business world as well as to guarantee the certainty and the rule of law, then the Government back in full about PT. Issuing law No. 1 of 1995 dated 7 March 1995 concerning limited liability company. With the limited liability company $\mathrm{ACT}$, provisions that regulate the PT in KUH Trademark was declared no longer valid. The next law No. 1 year 1995 concerning limited liability company has been replaced by Law No. 40 of 2007 regarding limited liability company (hereinafter as UUPT). Person or legal entity who will be holding a treaty creating a limited liability company, pouring the contents of the Covenant in the deed made by the notary deed and before then it is called a deed of establishment which contains statutes. People who set up then enter the Center named as shareholders means the owner of the company. ${ }^{8}$ Next to get the status of a legal entity must be authorized by the Minister of Justice and human rights. ${ }^{9}$

The deed of establishment itself contains provisions regarding the report and other information. This means that the existence of a basic budget is fused with a deed of establishment that so if reading the company's establishment deed has read the articles of Association of the company itself. Between by deed of establishment with basic budget can not be separated from each other.

\section{B. Method}

The writing of this juridical normative approach using the method. Through such approaches, this paper is focused to analyze the reasons that can lead to a limited liability company (PT) can be denied the permit Ruling Bodies by Kemenkumham through the analysis of limited liability legislation, data field through the media, and other related legislation. In addition, the writing is

8 Sutarno, Aspek-Aspek Hukum Perkreditan Pada Bank, Alpabeta, Bandung, 2005, pp. 2223; Husin, Jemmy Rumengan, and Idham Idham, "Juridical Analysis of the Role of Notary Accountability in Making Deed of Meeting Decree and Circular Decree of Limited Liability Companies (Research Study at the Indonesian Notary Association of Batam City)", International Journal Advances in Social Science and Humanities, Vol. 8 No. 6, 2020, pp. 26-35.

9 Article7(4) UUPT. The provision stated that the Company obtains legal entity status on the date of the issuance of a ministerial decree regarding the legalization of the Company's legal entity. See also Emy Widya, Paramita Prananingtyas, and Budi Ispriyarso. "Pelaksanaan Penerbitan Nomor Induk Berusaha Melalui Sistem Online Single Submission (Studi Pendirian Perseroan Terbatas di Kota Semarang)", NOTARIUS Vol. 12 No. 1, 2019, pp. 231-252. 
also analysing linkages between legislation related to each other. Therefore, the data used in the writing of this is secondary, i.e. data obtained from books and data published by institutions specifically limited liability company and the Ministry of Law and Human Rights itself.

\section{Results And Discussion}

As has been outlined above, that rather than permit the establishment and founding of a limited liability company (PT) should be done by using a formal Deed (deed made by a notary public) that where in it itself has been listed another name of a limited liability company, the then capital, line of business, company address, and so on. Notary deed also must have been authorized by the Minister of law and human rights Republic Indonesia (formerly Minister of Justice) itself to permit its founding limited company (PT) itself. ${ }^{10}$

\section{Mechanism of Establishment of Limited Liability Company in Indonesia}

To be able to set up a limited liability company (PT), has to be by using a formal Deed (deed made by a notary public) that mention another name telh limited liability company, the then capital, lines of business, company address, and others so on. This certificate must be authorized by the Minister of Law and Human rRights Republic Indonesia to get permission from the Minister of Justice, should be qualified as follows:

1) Limited Liability does not conflict with public order and morality.

2) The deed of establishment meeting the requirements in the legislation.

3) At least the specified and paid capital is $25 \%$ of the base. (in accordance with Law No. 1 of 1995 \& Law No. 40 of 2007, regarding limited liability company and either).

After getting the endorsement, before about limited liability company Act (Law No. 1 of 1995) limited company to be registered with the Court of the local area, but after the enactment of Law No. 1 of 1995, then the deed of

10 Dita Perwitasari, "Legal Certification in Electronic Credit Agreement," Journal of Private and Commercial Law, Vol. 2 No. 2, 2018, p.3. For further comparison, please also see Cezary Małozięć, "Participation in a Limited Liability Company as an Element of Marital Property", Law and Administration in Post-Soviet Europe Vol. 7 No.1, 2020, pp. 22-33; Daniel Hendrawan, et al. "Application of the Principles of Business Judgment in the Authoritative Function of Directors of Limited Liability Company in Singaporean and Indonesian Legal Perspectives", Academic Journal of Interdisciplinary Studies Vol. 9 No.3, 2020, pp. 93-93. 
establishment must registered to the company registration office (according to the list of mandatory law firm of the year 1982), in other words no longer need to be registered to the Court and to the country's development, but the Law No. 40 of 2007, liabilities registration in the Office of company registration in tiadakan as well. While the stages of announcement in the news of the Republic of Indonesia (BNRI) is still valid, it's just that the current Law No. 1 of 1995 applies this announcement is the duty of the Board of Directors of PT is concerned but in accordance with Law No. 40 of 2007 changes the authority/ the obligation of the Minister of Justice and human rights or simply the Ministry of Justice and human rights. ${ }^{11}$

After that stage passed then the company has gained the status of a legal entity and a limited liability company be themselves and be able to perform the agreement and the wealth of the company separate from the wealth of its owner. The company's basic capital is the amount of capital that is listed in the deed of establishment until the maximum amount when all shares issued. In addition to the basic capital, there is also a limited liability company in the capital has been placed, deposited capital and capital pay. capital is the amount of capital placed and accepted for inclusion, which at the time of its founding is the amount that is included by the founder and refines. Capital raising that included in the center of the company and the capital has been deposited in the form of money.

\section{The Division of Public Limited Company and Its Authority}

Limited Liability Companies in Indonesia are divided into several types as follows, namely:

a. Open Limited Liability Company (PT), Public Company

Open Limited Liability Company (PT) or Public Company open is a limited liability company that sells its shares to the public through the capital market (going Public). So, the shares offered to the public, for sale through the stock exchange and everyone has the right to buy shares of the company.

b. Closed Limited Liability Company (PT), Private Company

The sense of a Closed Limited Liability Company or Private Company itself is a limited liability company that his company's capital comes from certain circles i.e. for example from the shareholders that comes

11 Masnun Ali, "Legal Protection of the Right on Indication of Origin in Indonesia," Journal of Private and Commercial Law, Vol. 2 No. 2, 2018, pp. 2-3. 
only from relatives and family only or limited from it and can not be sold to the general public or circles.

c. PT Blank

Limited liability company (PT) empty is a limited liability company is not actively running his business and just live the name alone.

In a limited liability company (PT) is in addition to the wealth of company owners of capital and wealth in addition there is also a separation between company owners and managers of the company. Company managers can be handed over to the staff of professional experts in the field. organizational structure of a limited liability company consisting of shareholders, the Board of Directors. Commissioners. PT, shareholders gave the authority to the Board of Directors to run the company and develop in accordance with the purpose and scope of work of the company. with respect to the Board of Directors, authorized to represent the company rugas, agreement, contract and so on. When the occurrence of the harm is enormous (over 50\%) The Board of Directors must report it to shareholders and third parties, to a point.

The Commissioner has a function as a supervisor of the company's Board of Directors performance. The Commissioner may examine the bookkeeping, reprimand, the Board of Directors, even if the need to lay off the Board with GMS decision to take a host of Directors, then it will be dismissed or not. In GMS/General meeting of shareholders, all shareholders in the least must issue his voice. in the GMS yourself-discussed issues related to the evaluation of the performance and the company's policy that should be implemented immediately. When a shareholder is not able to, he can throw a voice to other holders of so-called proxy results AGM is usually assigned to the Commissioner forwarded to the Board of Directors to run.

1) The contents of the general meeting of shareholders:

2) setting the appointment of Directors and Board of Commissioners

3) lay off the Board of directors or Commissioners

4) establish gaj idireksi great and Commissioners

5) evaluating the company's performance

6) decide on a plan of addition/subtraction company Sahm.

7) determine corporate policy

8) Announces profit sharing (dividends).

\section{Capital Limited Liability Company}

As a legal entity, a limited liability company has the right, obligation, and the wealth of its own, in addition to the rights, obligations and property 
of the founder, shareholder and administrator. The company's wealth can be manifested in various forms of material, whether moving or not moving, as well as the tangible or intangible (right), all companies qualify as legal owner of the subject matter. On the balance sheet of the company, the company's fortunes can be found in the Group's "Private Equity's". Private equity capital in the company for each financial year which turned out to be in the company's annual report. This is a result of Remittance shareholders soon after the company gained the support of the Minister of Justice, namely, that look at the paid-in capital of the company. Paid-in capital should be the same with capital placed by the company, because of the limited liability company law requires that any stocks that have been fully paid up at the time issued the company gained further support and each time spending further shares to be paid in full. The company's capital is a wealth of good money or objects that are used by the company to run its business. ${ }^{12}$ Capital structure of the UUPT itself consists of:

1) authorized capital (authorized capital), that wealth in the form of money that you have specified the magnitude of which depends on the establishment of the company.

2) capital placed (placed capital), that wealth in the form of money that you have specified the percentage of authorized capital disanggupi by the founders at the time of the founding of the company.

3) paid-in capital (paid up capital), that wealth in the form of money that you have specified the percentage of capital placed paid in cash by the founders at the time of the founding of the company. ${ }^{13}$

Regarding the remittance of these shares in accordance with article 34 paragraph (1) of the limited company Law No. 40 of 2007, are:

(1) the remittance of capital above can be done in the form of cash and/or in other forms.

(2) in terms of share capital penyetoan is done in another form as referred to in paragraph (1), assessment of the capital stock of reserves is determined based on the fair value of which is set in accordance with market prices or by experts who are not affiliated with The company.

(3) deposit of the shares in the form of moving objects don't move should be announced in one or more newspapers, within

12 J. M. Perillo," The Statute of Frauds in the Light of the Functions and Disfunctions of Form", Fordham L. Rev. 39, 48-641974.

13 Abdulkadir Muhammad, Hukum Perseroan Indonesia, Citra Aditya Bakti, Bandung, 1995, pp. 195-197. See also Xavier Nugraha, Krisna Murti, and Saraswati Putri, "Third Parties' Legal Protection Over Agreed Authorized Capital Amount by Founders in Limited Liability Companies", Lentera Hukum Vol. 6 No. 2, 2019, pp. 173-188. 
fourteen (14) days after the deed of establishment was signed or after the AGM decides the stock delivery.

The explanation of such article, generally in the form of stock deposit money. However, do not close the possibility to deposit shares in other forms, either in the form of tangible objects or intangible objects, which can be assessed with money and which significantly have been accepted by the company. This stock should be accompanied by a remittance details outlining the value or price, type, status, or type of seat, and others as deemed necessary for the sake of clarity regarding deposits. The value of paid-in capitals determined in accordance with fair market value. If market value is not available, fair value is determined when the assessment techniques that best suit the characteristics of the deposit according to relevant information and best. ${ }^{14}$

\section{Shares of Limited Liability Company}

The stock is the manifestation of a capital company as said in article 31 of Law No. 40 of 2007 , that the capital of the company consists of the whole of the nominal value of the shares. Then in article 49 is determined the value of the shares should be listed in dollars, and shares without nominal value cannot be issued. This provision does not cover the possibility of legislation in the field of capital markets that set up the company's capital consists of shares without nominal value. Article 33 paragraph (3) of the ACT on public limited company no. 40 year 2007 stated that the expenditure shares itself further done every time to be able to raise capital have been placed must have paid in full.

Furthermore, as has been outlined previously above, that against the stock on behalf of this must have been paid in full at the time of the founding of the Act has been passed by the Minister of Justice. And this means that part of the payment of the price of the shares can only be made up to the time limit at the time the deed of establishment of affirmation. However, these shares on behalf of this can already published in the past despite existing stock price recently paid only partially, which is important at a time when this section of all shares that have been issued must be paid in full. ${ }^{15}$

14 Laksamana Adiyaksa, "Jangka Waktu Berdirinya Badan Hukum (Perseroan Terbatas) Dalam Kaitannya Dengan Perpanjangan dan Sekaligus Pembaharuan Hak Guna Usaha”, Thesis, Postgraduate Program, Universitas Sumatera Utara, Medan, 2007, pp. 108-110.

15 Agus Budiarto, Kedudukan Hukum dan Tanggung Jawab Pendiri Perseroan Terbatas, Ghalia Indonesia, Anggota IKAPI, Jakarta, 2002, p. 52. 
In contrast to the above, inventories will not be issued if the stock price has not been paid in full on the company's cash. It is as defined above can only indicate the stock is issued when the nominal value of the shares or value in Exchange for fully paid. When the note carefully the above articles may be sound, captured the intent of this provision is to protect company cash, because when the stock price up unpaid full point and then transferred to the other party when peralihannya so easy without requirements, only physically surrender from hand to hand, as a result it is expected that the company will be difficult demands repayment of stock prices because it is difficult to find and know the Top shareholders pointed to it. In addition the company will definitely suffer losses due to bear the brunt of the stock is empty. ${ }^{16}$ So that's the UUPT stated expressly that the top point of the stock can only be issued if the nominal value of the shares or the value of which has been paid in full. ${ }^{17}$

The company is obliged to set aside a certain amount can net income each year to spare. The usage of net profit itself is included in the determination of the amount of the allowance for the reserve that has been referred to is decided by the general meeting of shareholders (GMS) itself. The whole of the net income after deducting from the allowances to reserve that is distributed to shareholders as dividends, unless specified in the GMS. 18

The basic budget in an enterprise have established one or more classification of stocks. Each of these stocks have been in the same classification has given the holder the same rights, but in case there is more than one (1) classification of stocks, in a basic budget itself has set one of them as a common stock. Classification of the stock in question include: 19

1) the voting rights of shares with or without voting rights.

2) shares with special rights to be nominated as a member of the Board of Directors and/or members of the Board of Commissioners itself.

3) The stock after a certain period of pull back or exchanged for shares of the other classification.

16 Ibid., pp. 52-53.

17 Ibid., pp. 53-54.

18 Article 70(1) and Article 71(1) and (2) UUPT. It is stated that, the company is required to set aside a certain amount of net income for each financial year for reserves. The use of net profit including the determination of the amount of allowance for reserves as referred to in Article 70 paragraph (1) shall be decided by the GMS. All net profit after deducting the allowance for reserves as referred to in Article 70 paragraph (1) shall be distributed to shareholders as dividends, unless otherwise stipulated in the GMS.

19 Racmat Setiawan, Pokok-pokok Hukum Perikatan, Putra A. Bardin, Bandung, 1999, pp. 3-5. 
4) shares that entitles the holder to receive a dividend towards the classification of other top shareholder dividend distribution cumulatively or non-cummulative.

5) shares give the right to shareholders in other classification over the Division of the wealth of the remaining companies in liquidation. ${ }^{20}$

All shares issued and has been taken up by shareholders who are recorded in the list of shareholders or shares held by directors, most do not contain: 21

1) name and address of the shareholder

2) quantity, number, and date of acquisition of the shares of which are owned by shareholders, and the classification in terms of issued

3) more than one classification of stocks

4) the amounts deposited over any shares

5) the name and address of the person or legal entity perserorangan had been defamatory stock or as a guarantee of fiduciary

6) The recipient and date of acquisition of the shares of the liens or the date of registration of such fiduciary guarantee

7) save the stock information in other forms as mentioned in Article 34 paragraph (2).

Likeawise with the stock shape transition, it must be noted about the change of ownership, in the list of shareholders and special lists and notes as well as any change of ownership. The company is obliged to hold and save specific lists which contain information about the ownership of the shares of a member of the Board of Directors and Board of Commissioners with his family over the responsibilities and other obligations or on the date the shares are Retrieved. ${ }^{22}$

List of shareholders and special lists provided in the seat of the company in order to be seen by shareholders. According to Agus, Budiarto book list of shareholders can be a clue about anyone who is recorded in the list, so that it can be legally is an indicator of the actual status as the owner of the shares of PT. ${ }^{23}$

20 Article 53 UUPT

21 Article 50(1) UUPT. It was explained and affirmed that the Board of Directors of the Company is obliged to maintain and keep a register of shareholders, which contains at least: (a). names and addresses of shareholders; (b). the number, number, date of acquisition of shares owned by shareholders, and their classifications in the event that more than one classification of shares is issued; (c). the amount paid up for each share; (d). the name and address of an individual or legal entity that has pledge over shares or is the recipient of the share fiduciary security and the date of acquisition of the pledge or the date of registration of said fiduciary security; (e). information on payment of shares in other forms as referred to in Article 34 paragraph (2)

22 Ibid.

23 Agus Budiarto, Op. Cit., pp. 55-56. 


\section{How if the Authorized Failure? How if the Permission Denied?}

Good company other company names and profiteer of the Ministry of law and human rights or Kemenkumham as an authoritative institution pengesah the founding deed of establishment and articles of a limited liability company (PT), were both presented by the defendant, compulsory or at least make the authorities of the Ministry of law and human rights or Kemenkumham as a plundering of the defendants so as instructed subject to amar's ruling to revoke the endorsement of the establishment of the legal entity of the company that owns the name resembling names legal entities property of a limited liability company (PT) other parties in bad faith because the owner of the company that the company's other name, profiteer is a curious omission from the Ministry of law and human rights or Kemenkumham not accepted name the company is profiteer (though now much less likely to occur). ${ }^{24}$

It should be also understood the importance of the process of ratification of a legal entity, in order to have the legality as well as legal standing before the law and the courts. There is no Board of directors or the company's other organs without the endorsement of the company's legal entity by the authority. To that end, it should be ensured that the company that first (from the beginning) has a legal entity who has authorized its establishment by authorities, before it filed a lawsuit against a third party or legal entity interests related to on behalf of the Board of directors or the company's other organs concerned. ${ }^{25}$

Good business entities in the business scale of small, medium, large and very important to have a legal entity. Legal entities will protect business entities from any claims resulting from the activities performed by the company. A major feature of business entities incorporated there is separation of the legal owner of the wealth with a wealth of business entities, so the owner is only responsible for the extent of the property of the company. ${ }^{26}$

24 Bismar Nasution, Diktat Hukum Perusahaan, Universitas Sumatera Utara, 2003, pp. 12.

25 Paul L. Davies, Principle of Modern Company Law, London, Thomson Sweet \& Maxwell, 2003, pp. 10-15.

26 See, Regulation of the Minister of Law and Human Rights of the Republic of Indonesia Number: M.837-KP.04.11 of 2006 concerning Delegation of the Authority of the Minister of Law and Human Rights of the Republic of Indonesia in Providing Legal Entity for Limited Liability Companies to the Head of Regional Offices of the Ministry of Law and Human Rights throughout Indonesia [Peraturan Menteri Hukum dan HAM Republik 
1) The Filing Stage Name of Company

This process aims to review the name PT (does PT use name or not?). The filing of the company's name registered by the notary through administrative law system (Sisminbakum) of the Kemenkumham. As for the necessary requirements are as follows: 27

a. Attach the original form and the formation of a power of Attorney

b. Attach photocopies of identity cards of residents is the founder and the Executive Board of the company

c. Attach photocopies of family card Director/founder of PT

2) The Stages of Making the Deed of Establishment of Company

The making of the deed of establishment was done by the notary public authorities throughout the territory of the Republic of Indonesia to further get the pesetujuan from Kemenkumham. These certificates usually contain information about the name of the company, which is involved in anything, the name of the owners of capital, basic capital, paid-in capital, the supervisor is the company as a Director, the Director and Commissioner.

3) The Stage of Manufacture of Company Domicile Affidavits (SKDP) The letter you get from the Parish Office places your company is located. Based on this letter, the head of the issuance of the certificate. To obtain a certificate, you will need a copy of your certificate of domicile of your company. Other necessary requirements include: Photocopying of Earth and building tax (PBB) last year, the lease agreement or contract of business place to live not in Office buildings, residents Sign cards (KTP) Director, permit the wake (IMB) If PT is not in Office buildings . 28

4) The Stages Number of Petition for Taxpayer ID (NPWP).

To get a Tax ID, you need a copy of the company certificate and a certificate of residency. TAX ID application submitted to the Central Office of the Ministry of taxes in accordance with the other terms of domicile PT that is required, is a personal Tax ID: Director of PT, photocopy of ID or passport Photocopy (Director for. Foreign, PT special PMA), Deed, and the establishment of SKDP PT.

Indonesia Nomor: M.837-KP.04.11 Tahun 2006 tentang Pendelegasian Wewenang Menteri Hukum dan Asasi Manusia Republik Indonesia Dalam Memberikan Pengesahan Badan Hukum Perseroan Terbatas Kepada Kepala Kantor Wilayah Departemen Hukum dan Hak Asasi Manusia di Seluruh Indonesia].

27 "Pedoman Penggunaan Sistem Administrasi Badan Hukum (SISMINBAKUM)", Yayasan Kesejahteraan Direktorat Jenderal Administrasi Hukum Umum Departemen Kehakiman dan Hak Asasi Manusia, p. 1.

28 Anonim, Undang-Undang Perseroan Terbatas 2007 dan Penjelasannya, Gardien Mediatama, Yogyakarta, 2007, p. 51 
5) Stage of The Company's Articles of Association Endorsement by the Minister.

The petition is submitted to the Minister of Kemenkumham to get the support of the company's articles of Association (Statute).

6) Stage of The Filing of the Trade Business License (SIUP).

This gives the benefits so that PT can run its business activities. The given application, submitted to the head of Department of industry and trade and/or cooperative micro small medium enterprises and trade of the city or County of domicile in accordance with the related PT.

7) Stage of the Filing of the Mark Company List (TDP).

Application for registration is submitted to the head of Department of industry and trade and/or cooperative micro-small cities or counties and related trades in accordance with the company's domicile.

8) Stage News Events of the Republic of Indonesia (BNRI).

After the company doing the obligatory List of companies and has received the support of the Minister of Kemenkumham, then it should be in BNRI in the company announced that it has been posted at BNRI, then the PT has perfect its status as a legal entity. ${ }^{29}$

\section{Advantages of Forming a Limited Liability Company}

Unlike other partnerships, shareholders of the limited liability company (PT is not obligated to pay for the bonds and the debt of the company. As a result of lost's "unlimited" the potential can not exceed the amount that they have paid to the stock. This not only allows a company to carry out a risky venture for in itself, but it also limited liability also forms the basis for every stock trading company.

The company's assets and the structure can go through life from a shareholder, officer or Director. This causes the stability of capital (Economics), which can be an investment in the project is more besardan in a period of time longer than on a company's assets can still make the subject of the dissolution of the better pick up and spread. the advantage is also very important in the period pertengaha, while in the Church contribute to (a company) that will not collect feudal fees a landlord can claim when a landowner dies for this see Statute of Mortmain. ${ }^{30}$

29 Sastrawidjaja, Man S., Mantili Rai, Perseroan Terbatas Menurut Tiga Undang-Undang, PT. Alumni, Bandung, 2008, pp. 37-38.

30 Gunawan Widjaja, Seri Hukum Bisnis: Tanggung Jawab Direksi Atas Kepailitan Perseroan, Raja Grafindo Persada, Jakarta, 2003. pp. 127-128. See also Adam Travis, "The 
Furthermore, concerning efficiency management stated that management and specialization allows the processing of sehigga efficiency of capital allows to do the expansion. and by putting the right people, maximum efficiency of capital and also there is a separation between the Manager and the owner of the company, so it looks basic tasks and functions of each. The complexity of licensing and the Organization to set up a limited liability company (PT) is not easy. In addition to the cost of not a few, limited liability company (PT) it also requires the notary deed and special permission for certain undertakings. then with the magnitude of this company, the cost of organizing will come out very large. not to mention the hassle and obstacles that occur at the level of personnel. relationships between individuals are also more memorable formal and rigid. ${ }^{31}$

\section{Conclusion}

Law No 40 of 2007 decided the company was founded by two or more persons with a notary deed made in Indonesia language. This provision confirms the principles on the basis of this law which is basically a corporate legal entity established by a treaty, and therefore has more than one (1) person shareholders. After the company obtained the status of legal entities and shareholders less than 2 (two) years, then for a period of not longer than 6 (six) months from the country concerned shareholder shall be obliged to divert a portion of their shares to other parties or the company that issued the stock over to others. The laws on limited liability company no. 40 year 2007 decided the company was founded by two or more persons with a notary deed made in Indonesia language. This provision confirms the principles on the basis of this law which is basically a corporate legal entity established by a treaty, and therefore has more than one (1) person shareholders. After the company obtained the status of legal entities and shareholders less than 2 (two) years, then for a period of not longer than 6 (six) months from the country concerned shareholder shall be obliged to divert a portion of their shares to other parties or the the company that issued the stock over to others. The company acquired the status of a legal entity after the deed of establishment of a company that is authorized by the Minister of Law and Human Rights. In making the deed of establishment itself, the founder may be represented by

organization of neglect: Limited liability companies and housing disinvestment", American Sociological Review Vol.84 No. 1, 2019, pp. 142-170; Shawn Bayern, "The implications of modern business-entity law for the regulation of autonomous systems." Stanford Technology Law Review, Vol. 19 No. 7, 2015, pp. 93-111.

31 Muntinah, "Aspek Hukum Rapat Umum Pemegang Saham Perseroan Terbatas Melalui Telekonferensi", Thesis, Universitas Diponegoro, Semarang, 2010, pp. 69-70. 
another person based on power of Attorney, for example, from a notary public. The deed of establishment of the load and other information. This means that the article about the existence of that blend with the deed of establishment itself so if read the deed of establishment of companies actually then actually read the articles of Association of the company. Between the deed of establishment with its own statutes cannot be separated.

\section{E. Acknowledgment}

Authors would like to thank to colleagues at International Undergraduate Program Faculty of Law Universitas Negeri Semarang, as well to Research Community at Universitas Sebelas Maret for unvaluable support and advice.

\section{F. Declaration of Conflict of Interest}

The author states that there is no potential conflict of interest in the research, authorship, and/or publication of this article.

\section{G. Funding}

The author does not obtain financial support from any party for research, authorship, and/or publication of this article.

\section{H. References}

Adiyaksa, L. (2007). "Jangka Waktu Berdirinya Badan Hukum (Perseroan Terbatas) Dalam Kaitannya dengan Perpanjangan dan Sekaligus Pembaharuan Hak Guna Usaha", Thesis. Medan: Universitas Sumatera Utara.

Akram, M. H., \& Fanaro, N. P. (2019). Implementasi Doktrin Business Judgement Rule di Indonesia. Ganesha Law Review, 1(1), 77-87.

Anonim. Pedoman Penggunaan Sistem Administrasi Badan Hukum (SISMINBAKUM). Yayasan Kesejahteraan Direktorat Jenderal Administrasi Hukum Umum Departemen Kehakiman dan Hak Asasi Manusia.

Anonim. (2007). Undang-Undang Perseroan Terbatas 2007 dan Penjelasannya. Yogyakarta: Gardien Mediatama.

Atmaja, A. K., Kusumadara, A., \& Hamidah, S. (2018). Kedudukan Izin Prinsip Penanaman Modal Asing Badan Koordinasi Penanaman Modal Sebagai Dasar Pembuatan Akta Pendirian Perseroan Terbatas. Jurnal Selat, 6(1), 95-114. 
Bayern, S. (2015). The implications of modern business-entity law for the regulation of autonomous systems. Stanford Technology Law Review, 19(7), 93-111. Retrieved from https://law.stanford.edu/wpcontent/uploads/2017/11/19-1-4-bayern-final_0.pdf

Budiarto, A. (2002). Kedudukan Hukum dan Tanggung Jawab Pendiri Perseroan Terbatas. Jakarta: Ghalia Indonesia.

Crisandyna, M. K. T., Sumardika, I. N., \& Arini, D. G. D. (2020). Aspek Perizinan dalam Pendirian Perseroan Terbatas dengan Sistem Online Single Submission. Jurnal Interpretasi Hukum, 1(1), 118-123.

Davies, P. L. (2003). Principle of Modern Company Law. London: Thomson Sweet \& Maxwell.

Djaidir, D. (1997). "Undang-Undang Perseroan Terbatas", Presented in a One Day Seminar Regarding the Law on Mortgage Rights and the Law on Limited Liability Companies. Medan: Kantor Wilayah BRI Sumatera Utara, 21 June 1997.

Eriza, N., Azheri, B., \& Fauzi, W. (2019). Juridical Consequences of Amendments to the Articles of Association of a Limited Liability Company that are not recorded at the Ministry of Law and Human Rights in Indonesia. International Journal of Multicultural and Multireligious Understanding, 6(6), 430-439.

Hartono, S. R. (1995). "Beberapa Aspek Permodalan pada Perseroan Terbatas", Paper, presented on National Seminar at Universitas Gadjah Mada, Yogyakarta.

Hendrawan, D., Dewi, E. F., Sukarno, S., \& Mirzanti, I. R. (2020). Application of the Principles of Business Judgment in the Authoritative Function of Directors of Limited Liability Company in Singaporean and Indonesian Legal Perspectives. Academic Journal of Interdisciplinary Studies, 9(3), 93-93.

Husin, H., Rumengan, J., \& Idham, I. (2020). Juridical Analysis of the Role of Notary Accountability in Making Deed of Meeting Decree and Circular Decree of Limited Liability Companies (Research Study at the Indonesian Notary Association of Batam City). International Journal Advances in Social Science and Humanities, 8(6), 26-35. http://ijassh.com/index.php/IJASSH/article/viewFile/357/340

Kim, K. (2018). Matchmaking: Establishment of state-owned holding companies in Indonesia. Asia \& the Pacific Policy Studies, 5(2), 313330.

Masnun, M. (2018). Legal Protection of the Right to Indication of Origin in Indonesia. Journal of Private and Commercial Law, 2(2), 113-124. DOI: https://doi.org/10.15294/jpcl.v2i2.16875

Małozięć, C. (2020). Participation in a Limited Liability Company as an Element of Marital Property. Law and Administration in Post-Soviet Europe, 7(1), 22-33.

Muhammad, A. (1995). Hukum Perseroan Indonesia. Bandung: Citra Aditya Bakti. 
Muis, A. (2006). Hukum Persekutuan dan Perseroan. Medan: Sumatera Utara.

Muntinah, M. (2010). “Aspek Hukum Rapat Umum Pemegang Saham Perseroan Terbatas Melalui Telekonferens", Thesis. Semarang: Universitas Diponegoro.

Nasution, B. (2003). Diktat Hukum Perusahaan. Medan: Universitas Sumatera Utara.

Nugraha, X., Murti, K., \& Putri, S. (2019). Third Parties' Legal Protection Over Agreed Authorized Capital Amount by Founders in Limited Liability Companies. Lentera Hukum, 6(2), 173-188.

Perillo, J. M. (1974). The Statute of Frauds in the Light of the Functions and Disfunctions of Form. Fordham: L. Rev, 43(1), 39-82. https://ir.lawnet.fordham.edu/flr/vol43/iss $1 / 2$

Perwitasari, D. (2018). Legal Certification in Electronic Credit Agreement. Journal of Private and Commercial Law, 2(2), 125-133. DOI: https://doi.org/10.15294/jpcl.v2i2.16834

Republic of Indonesia. (2007). Law Number 40 of 2007 concerning Limited Libiability Company, State Gazette of Republic of Indonesia of 2007 Number 106, Additional State Gazette Number 4756 [UndangUndang Nomor 40 Tahun 2007 tentang Perseroan Terbatas, Lembaran Negara Republik Indonesia Tahun 2007 Nomor 106, Tambahan Lembaran Negara Republik Indonesia Nomor 4756], retrieved from https://www.ojk.go.id/sustainablefinance/id/peraturan/undang-undang/Documents/5.\%20UU-402007\%20PERSEROAN\%20TERBATAS.pdf

Republic of Indonesia. (2006). Regulation of the Minister of Law and Human Rights of the Republic of Indonesia Number: M.837-KP.04.11 of 2006 concerning Delegation of the Authority of the Minister of Law and Human Rights of the Republic of Indonesia in Providing Legal Entity for Limited Liability Companies to the Head of Regional Offices of the Ministry of Law and Human Rights throughout Indonesia [Peraturan Menteri Hukum dan HAM Republik Indonesia Nomor: M.837KP.04.11 Tahun 2006 tentang Pendelegasian Wewenang Menteri Hukum dan Asasi Manusia Republik Indonesia dalam Memberikan Pengesahan Badan Hukum Perseroan Terbatas Kepada Kepala Kantor Wilayah Departemen Hukum dan Hak Asasi Manusia di Seluruh Indonesia], retrieved from http://ditjenpp.kemenkumham.go.id/arsip/bn/2007/bn14-2007.htm

Sastrawidjaja, M., \& Mantili, R. (2008). Perseroan Terbatas Menurut Tiga Undang-Undang. Bandung: Alumni.

Setiawan, R. (1999). Pokok-pokok Hukum Perikatan. Bandung: Putra A. Bardin.

Soerodjo, I. (2018). Juridical Implication of Share Cross Holding According to Limited Liability Company Law in Indonesia. Journal of Legal, Ethical and Regulatory Issues, 21(2), 1-18. 
Sutarno, S. (2005). Aspek-Aspek Hukum Perkreditan Pada Bank. Bandung: Alpabeta.

Travis, A. (2019). The organization of neglect: Limited liability companies and housing disinvestment. American Sociological Review, 84(1), 142170.

Widjaja, G. (2003). Seri Hukum Bisnis: Tanggung Jawab Direksi Atas Kepailitan Perseroan. Jakarta: Raja Grafindo Persada.

Widya, E., Prananingtyas, P., \& Ispriyarso, B. (2019). Pelaksanaan Penerbitan Nomor Induk Berusaha Melalui Sistem Online Single Submission (Studi Pendirian Perseroan Terbatas di Kota Semarang). NOTARIUS, 12(1), 231-252. 